\title{
DETERMINASI PENGUNGKAPAN TRANSAKSI PIHAK BERELASI BERDASARKAN PSAK NO. 7 TAHUN 2018
}

\author{
Jessyka Tridewi Purba ${ }^{1}$, Husnah Nur Laela Ermaya ${ }^{2}$, Ayunita Ajengtiyas ${ }^{3}$ \\ 1,2,3 Universitas Pembangunan Nasional "Veteran" Jakarta, Indonesia \\ Email: jessykatridewi@gmail.com
}

\begin{abstract}
This study aims to examine the effect of audit committee, independent commissioner, institutional ownership, managerial ownership, earnings management to related party transaction disclosure. The samples used in this study are listed manufactured companies in 2016-2018. The total sample is 53 companies. The sampling technique that used is purposive sampling. The results of the study show that institutional ownership and managerial ownership significantly influence the disclosure of related party transactions. While the audit committee, independent commissioners and earnings management do not affect the disclosure of related party transactions. Companies are still more concerned about paying attention to financial information such as financial ratio analysis than non-financial information such as disclosure of related party transactions. Companies should pay more attention to non-financial which is useful for users of financial statements.
\end{abstract}

Keywords: related party, corporate governance, earnings management

\section{ABSTRAK}

Penelitian ini bertujuan untuk menguji pengaruh komite audit, komisaris independen, kepemilikan institusional, kepemilikan manajerial, manajemen laba terhadap pengungkapan transaksi pihak terkait. Sampel yang digunakan dalam penelitian ini adalah perusahaan manufaktur yang terdaftar di Bursa Efek Indonesia pada tahun 2016-2018. Total sampel penelitian ini adalah 53 perusahaan. Teknik pengambilan sampel yang digunakan adalah purposive sampling. Hasil penelitian menunjukkan bahwa kepemilikan institusional dan kepemilikan manajerial secara signifikan mempengaruhi pengungkapan transaksi pihak berelasi. Komite audit, komisaris independen, dan manajemen laba tidak mempengaruhi pengungkapan transaksi pihak berelasi. Perusahaan masih cenderung untuk memberi perhatian mengenai informasi keuangan seperti analisis rasio keuangan dibandingkan informasi non-keuangan seperti pengungkapan transaksi pihak terkait. Sebaiknya perusahaan memberi perhatian lebih atas informasi non-keuangan yang berguna untuk para pengguna laporan keuangan.

Kata kunci: pihak berelasi, tata kelola perusahaan, manajemen laba

\section{KETERANGAN ARTIKEL}

Riwayat Artikel: diterima: 2 Februari 2020; direvisi:30 Maret 2020; disetujui: 3 Juni 2020

Klasifikasi JEL: M4, M41

Cara Mensitasi: Purba, Jessyka T, dkk. (2020). Determinasi Pengungkapan Transaksi Pihak Berelasi Berdasarkan Psak No. 7 Tahun 2018. JIAFE (Jurnal Ilmiah Akuntansi Fakultas Ekonomi), 6(1), 29-40. https://doi.org/10.34204/jiafe.v6i1.1849

Copyright@2020. JIAFE (Jurnal IImiah Akuntansi Fakultas Ekonomi) Universitas Pakuan

\section{PENDAHULUAN}

Pengungkapan merupakan penyampaian informasi-informasi yang ada dalam perusahaan yang disampaikan oleh manajemen untuk para pengguna laporan keuangan. Teori agensi menunukkan hubungan kontrak kerja antara pihak yang memberikan wewenang dalam hal ini disebut sebagai prinsipal dengan pihak yang menerima wewenang yang disebut agen. Hamdani (2016) 
menjelaskan bahwa faktor pemicu terjadinya masalah keagenan karena adanya asimetri informasi yang disebabkan oleh lebih banyaknya keterlibatan agen secara langsung dalam pengelolaan perusahaan diabandingkan prinsipal, sehingga agen cenderung memiliki kemampuan dalam mengendalikan informasiinformasi dan keputusan operasional perusahaan. Ketimpangan kepemilikan informasi antara kedua pihak mengakibatkan prinspial kesulitan dalam mengendalikan tindakan agen.

Salah satu peraturan standar akuntansi keuangan yaitu PSAK No. 7 mengenai Pengungkapan Transaksi Pihak Berelasi. Keberadaan PSAK No. 7 yaitu mengenai Pengungkapan Pihak-Pihak Berelasi. PSAK No. 7 ini disahkan oleh DSAK IAI per tanggal 19 Februari 2010 dan telah mengubah PSAK No. 7 (1994) sebelumnya tentang Pengungkapan Pihak-Pihak yang Mempunyai Hubungan Istimewa. Standar akuntansi yang berlaku efektif per 1 Januari 2018 mengenai Pengungkapan Transaksi Pihak-Pihak Berelasi sebelumnya juga telah mengalami pengesahan revisi kembali pada 18 November 2015. Pernyataan ini dibuat dengan tujuan untuk membuat keyakinan terkait laporan keuangan telah melakukan pengungkapan yang cukup mengenai pihak-pihak berelasi.

Berdasarkan keputusan Badan Pengawas Pasar Modal dan Lembaga Keuangan Nomor: KEP-412/BL/2009, perusahaan terbuka atau perusahaan terkendali yang melakukan transaksi afiliasi harus mengungkapkan seluruh informasi dari setiap transakasi yang mencakup jenis transaksi, pihak yang bertransaksi, hubungan afiliasi, dan nilai transaksi. Pada umumnya transaksi pihak berelasi terkait dengan tujuan perpajakan. Munculnya transaksi-transaksi pihak berelasi karena ada tujuan untuk penghindaran atas kewajiban pajaknya (Izzaty dan Kurniawan, 2018).

Kasus adanya penyalahgunaan dari transaksi berelasi yang terjadi di Indonesia yaitu adanya dugaan penghindaran pajak yang dilakukan oleh PT Bentoel International Investama Tbk (kode emiten RMBA). RMBA melakukan strategi pinjaman yang bersumber dari perusahaan afiliasi di Jersey melalui perusahaan afiliasi di Belanda demi menghindari tingginya potongan pajak atas pembayaran bunga kepada non-penduduk sekitar 20\%, hal ini terjadi karena adanya perjanjian Indonesia dengan Belanda mengenai pembebasan pajak terkait pembayaran utang sehingga pajaknya menjadi 0\%. Kasus lain pada tahun 2019 terkait informasi laporan keuangan dari PT Tiga Pilar Sejahtera Food Tbk (kode emiten AISA) tahun 2017 atas manajemen baru AISA disebutkan bahwa adanya overstatement laporan keuangan sebesar Rp4 triliun dalam piutang usaha perusahaan, persediaan perusahaan, dan aset tetap Grup AISA. Pun, dugaan aliran dana Rp1,78 triliun yang terjadi kepada beberapa pihak yang diduga memiliki hubungan dengan pihak manajemen yang lama. Di samping hal tersebut, terdapat hubungan dan transaksi dengan pihak terafiliasi dengan menyampingkan mekanisme pengungkapan yang memadai kepada pihak stakeholders. Hal ini diidentifikasi telah menentang Keputusan BAPEPAM-LK No.KEP-412/BL/2009 tentang Transaksi Afiliasi dan Benturan Kepentingan Transaksi Tertentu.

Beberapa hal seperti rendahnya tingkat penegakan hukum, implementasi good corporate governance, dan pengungkapan pihak berelasi merupakan faktor yang menyebabkan permasalahan terkait pihak berelasi sulit untuk dideteksi (Harijanto, 2019). Kehadiran komite audit dan komisaris independen di perusahaan diharapkan akan membentuk tata kelola perusahaan menjadi baik. Pihak-pihak ini diharapkan akan membatasi dan mengawasi aktivitas manajemen serta mendukung transparansi pengungkapan transaksi pihak berelasi. Penelitian Izzaty dan Kurniawan (2018) dan Pratista (2019) menyatakan bahwa komite audit dan komisaris independen memiliki 
pengaruh atas pengungkapan transaksi pihak berelasi sedangkan Alvionita dan Taqwa (2014) menjelaskan bahwa mekanisme corporate governance yang terdiri dari komite audit dan komisaris independen tidak memiliki pengaruh atas tingkat kepatuhan pengungkapan wajib perusahaan.

Karakteristik entitas yang berada di Indonesia pada umumnya bercirikan kepemilikan keluarga akan cenderung melakukan praktik transaksi pihak berelasi baik antar perusahaan induk, perusahaan anak, maupun antar cabang perusahaan (Pratista, 2019). Berdasarkan survei yang dilakukan oleh PwC pada tahun 2014, yang menemukan bahwa lebih dari 95\% bisnis yang ada di Indonesia adalah bisnis keluarga dan perusahaan terbuka di Asia Tenggara tergolong perusahaan keluarga sebesar $60 \%$.

Struktur kepemilikan perusahaan juga diharapkan akan mampu mempengaruhi tingkat pengungkapan. Banyaknya pihak yang mengharapkan keterbukaan informasi mengenai perusahaan, maka perusahaan memiliki keharusan yang lebih besar juga terhadap pengungkapan yang akan dilakukan.

Menurut Partista (2019), adanya pengaruh luas antara pengungkapan transaksi pihak berelasi dengan kepemilikan institusional dan manajerial. Namun, Izzaty dan Kurniawan (2018) dan Gunawan (2016) tidak menemukan adanya pengaruh antara kepemilikan institusional dan kepemilikan manajerial dengan pengungkapan wajib perusahaan.

Harijanto (2019) menyatakan terdapat tiga hal mengapa perusahaan dalam mengadakan transaksi dengan pihak berelasi, yaitu pertama efisiensi dengan tujuan mengurangi biaya transaksi, kedua melakukan aktivitas peralihan sumber daya dengan cara tunneling, ketiga memanipulasi laba atau keuntungan perusahaan. Berbagai kondisi akibat transaksi pihak berelasi mampu membuka peluang munculnya penyelewengan transaksi yang dapat merugikan para pemegang saham minoritas (nonpengendali) dan memberikan keuntungan bagi pemilik saham pengendali (Pratista, 2019). Kondisi di mana pihak manajemen memanfaatkan adanya fleksibilitas dalam menyusun laporan keuangan akan memicu terjadinya praktik manajemen laba. Manajemen cenderung menunjukkan kinerja positif, sehingga akan memicu penetapan berbagai metode akuntansi untuk menghasilkan laba yang diinginkan. Manajer selaku pihak yang diberikan kewenangan dalam mengatur perusahaan akan mengetahui lebih banyak informasi dalam perusahaan dibandingkan dengan pemilik, sehingga manajer wajib untuk mengungkapkan informasi seluasnya kepada pemilik. Keadaan di mana manajer cenderung menyampaikan sesuatu yang berbeda dengan kenyataan yang sebenarnya dapat diketehui sebagai asimetri informasi. Hal in yang mampu membuka peluang untuk melakukan earning management (Ermaya dan Astuti, 2017).

Penelitian Lobu dan Zhou (2001) menunjukkan bahwa manajemen laba berhubungan negatif dengan pengungkapan informasi keuangan. Hal yang berbeda dijelaskan oleh Prior dkk.. (2008) yang membuktikan bahwa tindakan manajemen laba memiliki dampak signifikan positif terhadap tingkat pengungkapan, sedangkan penelitian oleh Fitri (2012) menjelaskan bahwa tindakan manajemen laba tidak memiliki dampak yang signifikan atas tingkat pengungkapan laporan keuangan per tahunan.

Sebelumnya penelitian mengenai pengungkapan wajib dan sukarela dalam laporan keuangan lebih banyak dilakukan dibandingkan penelitian mengenai pengungkapan transaksi pihak berelasi. Penelitian ini mengacu pada penelitian Pratista (2019) dengan judul Pengaruh Corporate Governance Pada Kepatuhan Pengungkapan Transaksi Pihak Berelasi Berdasarkan PSAK No. 7 Tahun 2015. Hasilnya menunjukkan bahwa komite audit, kepemilikan manajerial, dan komisarsis 
Jessyka Tridewi Purba: Determinasi Pengungkapan Transaksi ...

independen memiliki pengaruh atas luas pengungkapan transaksi dari pihak berelasi, sedangkan kepemilikan institusi tidak memiliki dampak terhadap luas pengungkapan transaksi pihak bereasi. Pembeda antara penelitian ini dengan penelitian yang dilakukan sebelumnya terlihat pada penambahan faktor manajemen laba dan sampel perusahaan dan tahun penelitian. Dengan demikian, dapat dikatakan bahwa penelitian mengenai pengungkapan transaksi pihak berelasi masih tergolong baru dibandingkan pengungkapan laporan keuangan lainnya.

\section{KAJIAN LITERATUR DAN PENGEMBANGAN HIPOTESIS \\ Teori Agensi}

Teori agensi berbicara mengenai hubungan atas kontrak kerja sama dari pihak yang memberikan kepercayaan, yaitu prinsipal dengan pihak yang menerima kepercayaan yaitu agen. Adanya perbedaan kepemilikan atas informasi yang ada di perusahaan dapat memicu terjadinya agency problem. Penyampaian informasi secara transparan dan sesuai dengan kondisi yang sebenarnya digunakan sebagai dasar bagi prinsipal dalam mengambil keputusan. Untuk memperkecil terjadinya agency problem, maka informasi yang ada dalam perusahaan diharapkan dapat disampaikan dengan metode pengungkapan yang seluas-luasnya.

\section{Komite Audit}

Keberadaan komite audit diharapkan akan mampu mengawasi seluruh aktivitas manajemen dalam mengelola perusahaan. Akmyga dan Mita (2015) menjelaskan bahwa komite audit yang bekerja secara efektif selain mampu mendorong pengendalian internal berjalan dengan baik juga akan mendukung perusahaan untuk patuh terhadap standar akuntansi dan peraturan yang berlaku, yaitu pengungkapan pihak berelasi. Penelitian Izzaty dan Kurniawan (2018) dan Pratista (2019) mengemukakan bahwa komite audit berpengaruh akan kepatuhan perusahaan dalam melakukan pengungkapan transaksi pihak berelasi.

\section{$\mathrm{H}_{1}$ : Komite audit berpengaruh terhadap} pengungkapan transaksi pihak berelasi

\section{Komisaris Independen}

Penerapan corporate governance diharapkan akan dapat berjalan dengan baik karena adanya peran dari komisaris independen. Kehadiran pihak independen dalam perusahaan akan meminimalisir terjadinya konflik selisih kepentingan yang terjadi pada pihak manajemen dan pihak pemegang saham. Hubungan antara komisaris independen dengan pengungkapan transaksi pihak berelasi pernah diteliti oleh Alvionita dan Taqwa (2014) dan Izzaty dan Kurniawan (2018) yang menunjukkan bahwa pengawasan oleh komisaris independen akan terlepas dari kepentingan manapun dan menjamin tata kelola perusahaan berjalan dengan baik serta akan memicu transaparansi dalam pengungkapan atas transaksi pihak berelasi.

$\mathrm{H}_{2}$ : Komisaris independen berpengaruh terhadap pengungkapan transaksi pihak berelasi

\section{Kepemilikan Institusional}

Berdasarkan teori keagenan, adanya perbedaan kepemilikan akan menimbulkan masalah keagenan. Harijanto (2019) mengungkapkan bahwa struktur kepemilikan juga dapat mempengaruhi pengungkapan. Kepemilikan institusional diharapkan akan mampu mempengaruhi perusahaan dalam melakukan pengungkapan atas informasi dalam perusahaan. Dibandingkan pemegang saham lainnya, investor institusional akan melakukan tindakan pengawasan yang lebih ketat atas setiap aktivitas yang dilakukan oleh manajemen. Hubungan antara kepemilikan institusional dengan pengungkapan transaski pihak berelasi pernah diteliti sebelumnya oleh Pratista (2019) dan Alvionita dan Taqwa (2014) yang menyimpulkan bahwa kepemilikan institusional yang terdapat di 
perusahaan berpengaruh kepada tingkat kepatuhan pengungkapan wajib.

$\mathrm{H}_{3}$ : Kepemilikan institusional berpengaruh terhadap pengungkapan transaksi pihak berelasi

\section{Kepemilikan Manajerial}

Penyebab dari timbulnya masalah antara agen dan prinsipal berawal dari ketidaksamaan dan ketidakselarasaan kepentingan antara prinsipal dan agen. Sering kali manajemen selaku agen bertindak diluar kepetingan prinsipal sehingga perilaku manajemen cenderung untuk mencari celah dalam mengutamakan kepetingan pribadinya. Kepemilikan saham oleh manajemen diharapkan akan mampu mengurangi masalah keagenan karena manajemen dalam hal ini tidak hanya akan bertindak di posisi pengelola perusahaan saja namun manajemen juga akan berada pada posisi sebagai pemilik modal. Oleh sebab itu, hal yang akan dikerjakan oleh manajemen menjadi sepadan dengan keinginan para pemegang saham pada umumnya, satu diantaranya yaitu megharapkan transparansi laporan keuangan. Penelitian yang dilakukan oleh Pratista (2019) dan Izzaty dan Kurniawan (2018) menyimpulkan bahwa kepemilikan saham oleh manajemen memiliki pengaruh terhadap ketaatan perusahaan dalam melakukan pengungkapan atas transaksi pihak berelasi.

$\mathrm{H}_{4}$ : Kepemilikan manajerial berpengaruh terhadap pengungkapan transaksi pihak berelasi

\section{Manajemen Laba}

Tindakan oportunis yang dilakukan oleh agen mencerminkan bahwa agen memiliki tujuan yang berbeda dengan prinsipal. Pada dasarnya, agen akan cenderung bertindak sesuatu yang dapat memberi keuntungan bagi pribadinya dibanding keinginan para investor (Prior dkk.., 2008). Tindakan manajemen laba dilakukan untuk menentukan keputusan yang dilakukan manajemen dalam memilih untuk menyajikan informasi lebih banyak maupun sedikit dalam laporan keuangan yang akan disampaikan. Hasil penelitian Lobu dan Zhou (2001) menjelaskan bahwa ada hubungan arah negatif diantara manajemen laba dengan pengungkapan atas infromasi dalam laporan keuangan. Prior dkk. (2008) menyatakan bahwa manajemen laba yang dilakukan perusahaan berpengaruh signifikan dan positif pada luas pengungkapan.

$\mathrm{H}_{5}$ : Manajemen laba berpengaruh terhadap pengungkapan transaksi pihak berelasi

\section{METODE PENELITIAN}

\section{Populasi dan Sampel}

Metode penelitian yang dipakai adalah metode deskriptif kuantitatif. Adapun populasi dari penelitian ini ialah entitas manufaktur yang listed di Bursa Efek Indonesia (BEI) periode 2016-2018, serta total sampel yang digunakan sebesar 53 perusahaan. Pengambilan sampel menggunakan metode purposive sampling. Metode purposive sampling menggunakan beberapa kriteria yang telah ditentukan sebelumnya, yaitu perusahaan yang tergolong manufaktur yang listed di BEI pada tahun 2016-2018 dan sudah menerbitkan laporan keuangan periode 20162018 secara berturut-turut. Perusahaan yang tergolong BUMN dikecualikan dari sampel karena memiliki perlakuan yang berbeda dalam PSAK No. 7, perusahaan telah menerapkan PSAK No. 7 revisi tahun 2014 dan perusahaan yang mempunyai persentase dari komisaris independen lebih banyak $30 \%$ sesuai dengan POJK Nomor 33/POJK.04/2014 tentang Direksi dan Dewan Komisaris Emiten atau Perusahaan Publik.

\section{Definisi Operasional dan Pengukuran Variabel Dependen}

Variabel terikat dalam penelitian ini ialah pengungkapan transaksi pihak berelasi. Berpacu pada poin pengungkapan menurut PSAK 7, adapun jabaran dari total pengungkapan yang akan dipakai diantaranya 
yaitu: Pertama, sifat dan hubungan antar pihak berelasi. Kedua, kompensasi manajemen kunci secara lengkap. Ketiga, jumlah transaksi. Keempat, jumlah saldo. Kelima, komitmen yang diantaranya syarat, ketentuan, jaminan. Keenam, penyisihan dari piutang ragu-ragu. Ketujuh, beban yang diakui atas piutang raguragu atau penghapusan piutang dari pihak berelasi.

Nilai pengungkapan diperoleh atas perbandingan nilai pengungkapan dengan total pengungkapan yang seharusnya (Harijanto, 2019):

$$
\mathrm{Y}=\frac{\text { Nilai Pengungkapan }}{\text { Total Pengungkapan Seharusnya }}
$$

\section{Variabel Independen \\ Komite Audit $\left(\mathbf{X}_{1}\right)$}

Komite audit dapat dilihat dari banyaknya jumlah dari anggota komite audit dalam satu perusahaan. Pada penelitian ini, proksi komite audit dilakukan dengan menghitung jumlah anggota komite audit di perusahaan tersebut (Izzaty dan Kurniawan, 2018), dengan rumus:

$$
\mathrm{X} 1 \text { = Jumlah anggota komite audit (2) }
$$

\section{Komisaris Independen $\left(X_{2}\right)$}

Alvionita dan Taqwa (2014) menyatakan proporsi dari komisaris independen diperoleh dari membandingkan jumlah anggota komisaris independen dan jumlah seluruh dewan komisaris perusahaan, dengan rumus:

$$
\mathrm{X} 2=\frac{\text { Jumlah komisaris independen }}{\text { Total dewan komisaris }}
$$

\section{Kepemilikan Institusional $\left(X_{3}\right)$}

Kepemilikan saham oleh institusi diperoleh dengan meperbandingkan proporsi jumlah saham yang dimiliki oleh institusi terhadap jumlah saham perusahaan yang beredar (Pratista, 2019), dengan rumus:
X3 $=\frac{\text { Total kepemilikan institusoional }}{\text { Jumlah saham yang beredar }}$

\section{Kepemilikan Manajerial $\left(\mathrm{X}_{4}\right)$}

Kepemilikan manajerial dalam penelitian ini dilakukan dengan cara membandingkan proporsi kepemiliksn saham oleh manajemen perusahaan terhadap total seluruh saham yang beredar (Akmyga dan Mita, 2015), dengan rumus:

$$
\mathrm{X} 4=\frac{\text { Total kepemilikan manajerial }}{\text { Jumlah saham yang beredar }}
$$

\section{Manajemen Laba $\left(\mathbf{X}_{5}\right)$}

Proksi untuk mengukur manajemen laba dalam penelitian ini memakai Modified Jones Model, sebab model ini dipandang merupakan model yang terbaik untuk menemukan apakah perusahaan terindikasi terjadinya praktik manajemen laba (Sulistyanto, 2008 p. 225). Sebelum melakukan perhitungan diskresioner akrual, maka diawali dengan menghitung total akrual, dengan rumus sebagai berikut:

$$
\mathrm{TACC}_{\mathrm{it}}=\mathrm{NI}_{\mathrm{it}}-\mathrm{CFO}_{\mathrm{it}}
$$

Kemudian perhitungan nondiscretionary accrual menggunakan regresi linear $\mathrm{TACC}_{i t}$ per $\mathrm{A}_{\mathrm{it}-1}$ dan akan menghitung discretionary accrual dengan menggunakan rumus seperti dibawah ini:

$$
\mathrm{DA}_{\mathrm{it}}=\frac{\mathrm{TACC}_{\mathrm{it}}}{\mathrm{A}_{\mathrm{it}-1}}-\mathrm{NDA}_{\mathrm{it}}(7)
$$

\section{Ukuran Perusahaan (Variabel Kontrol)}

Variabel kontrol dalam penelitian ini adalah ukuran perusahaan yang diproksikan dengan logaritma natural atas total aset yang dimiliki oleh perusahaan (Devi, 2014) dengan rumus:

$$
\text { Ukuran Perusahaan }=\text { Ln total aset }
$$

\section{Teknik Analisis Data}

Berikut ialah model dari regresi berganda penelitian ini: 


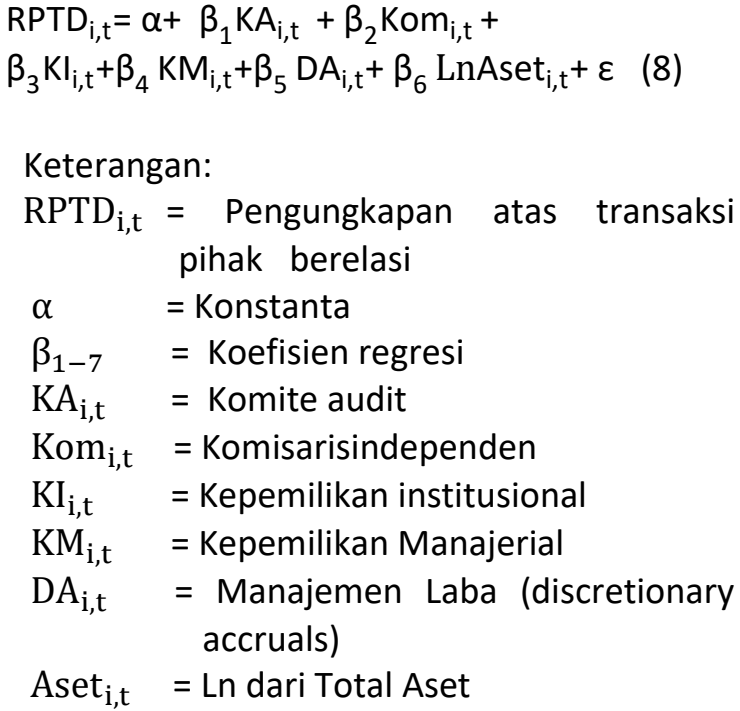

\section{HASIL PENELITIAN DAN PEMBAHASAN}

\section{Uji Normalitas}

Uji normalitas menggunakan uji analisis grafik dan analisis statistik (Ghozali, 2018 p.161). Analisis statistk yang digunakan ialah analisis statistik non-parametik Kolmogorov-Smirnov (K-S) Test. Hasilnya menunjukkan bahwa data dalam penelitian ini terdistribusi normal karena memiliki nilai Asymp. Sig (2-tailed) sebesar 0,090 atau lebih besar dari nilai signifikansi sebesar 0,050.

Tabel 1. Kolmogorov-Smirnov Test Unstandardized Residual

\begin{tabular}{l|l|r}
\hline $\mathrm{N}$ & 127 \\
\hline Normal & Mean & 0,0000000 \\
\cline { 2 - 3 } Paramters & Std. & 0,21624614 \\
& Deviation & \\
\hline \multirow{2}{*}{$\begin{array}{l}\text { Eost } \\
\text { Differences }\end{array}$} & Absolute & 0,073 \\
\cline { 2 - 3 } & Positive & 0,073 \\
\cline { 2 - 3 } & Negative & $-0,062$ \\
\hline Tess Statistic & 0,073 \\
\hline \multicolumn{2}{l|}{ Asymp. Sig (2-tailed) } & 0,090 \\
\hline \multicolumn{2}{c|}{ Sumber: Data diolah }
\end{tabular}

\section{Uji Heterokedastisitas}

Uji heterokedastisitas bermaksud untuk melihat apakah terjadi ketidaksamaan variance dari residual atau pengamatan ke pengamatan yang lain dalam model regresis, maka disebut homokedastisitas dan apabila berbeda disebut heterokedastisitas (Ghozali, 2018 p.137). Uji heterokedastisitas yang diterapkan dalam penelitian ini yaitu Uji Glejser. Hasilnya menunjukkan bahwa seluruh variabel tidak mengalami masalah heterokedastisitas terlihat dari nilai signifikansi diatas 0,05.

Tabel 2. Hasil Uji Glejser

\begin{tabular}{cc}
\hline Model & Sig. \\
\hline KA & 0,283 \\
\hline KOM & 0,344 \\
\hline KI & 0,051 \\
\hline KM & 0,171 \\
\hline DA & 0,451 \\
\hline ASET & 0,259 \\
\hline
\end{tabular}

Sumber: Data diolah

\section{Uji Multikolinearitas}

Penelitian ini tidak menunjukan adanya masalah multikolinearitas karena rentang nilai yang sempit antara 0,90 hingga 1,2. Dengan demikian, disimpulkan tidak terjadi korelasi diantara variabel independen pada penelitian ini.

\begin{tabular}{l|c|c}
\hline \multirow{2}{*}{ Variabel } & \multicolumn{2}{|c}{$\begin{array}{c}\text { Colinearity } \\
\text { Statistics }\end{array}$} \\
\cline { 2 - 3 } & Tolerance & VIF \\
\hline KA & 0,923 & 1,083 \\
\hline KOM & 0,870 & 1,150 \\
\hline KI & 0,864 & 1,157 \\
\hline KM & 0,932 & 1,073 \\
\hline DA & 0,994 & 1,006 \\
\hline ASET & 0,836 & 1,195 \\
\hline
\end{tabular}

Tabel

3.

Hasil

Uji

Multik

olinea

ritas 
Jessyka Tridewi Purba: Determinasi Pengungkapan Transaksi ...

Uji Model Regresi Berganda

Tabel 4. Hasil Uji Model Regresi Berganda

\begin{tabular}{l|c|c|c|c|c}
\hline \multirow{2}{*}{ Model } & \multicolumn{2}{|c|}{$\begin{array}{c}\text { Unstandardized } \\
\text { Coefficients }\end{array}$} & $\begin{array}{c}\text { Standardized } \\
\text { Coefficients Beta }\end{array}$ & $\boldsymbol{t}$ & Sig. \\
\cline { 2 - 5 } & $\mathbf{B}$ & Std.Eror & $-0,576$ & $-1,139$ & $\mathbf{0 , 2 5 7}$ \\
\hline (Constant) & 0,000 & 0,292 & $-0,239$ & $-1,207$ & $\mathbf{0 , 2 3 0}$ \\
\hline KA & $-0,123$ & 0,114 & $-0,173$ & $-1,939$ & $\mathbf{0 , 0 5 5}$ \\
\hline KOM & $-0,049$ & 0,051 & $-0,054$ & $-2,131$ & $\mathbf{0 , 0 3 5}$ \\
\hline KI & 0,029 & 0,014 & $-0,028$ & $-3,766$ & $\mathbf{0 , 0 0 0}$ \\
\hline KM & 0,006 & 0,004 & 0,012 & 0,475 & $\mathbf{0 , 6 3 5}$ \\
\hline DA & $-0,011$ & 0,015 & $-0,004$ & $-0,259$ & $\mathbf{0 , 7 9 6}$ \\
\hline LnASET & 0,010 & 0,009 & & & \\
\hline Adjusted R & 0,130 & & &
\end{tabular}

Sumber: Data diolah

Berlandaskan tabel 4 hasil dari uji model regresi tersebut diketahui nilai koefisien regresi pada variabel komite audit (KA) adalah sebesar 0,239 dan bertanda negatif, dengan nilai signifikansi yaitu 0,230. Maka dapat dikatakan bahwa jumlah komite audit tidak memiliki pengaruh yang signifikan atas pengungkapan transaksi pihak berelasi. Nilai dari koefisien regresi pada variabel komisaris independen (KOM) yaitu 0,173 dan bertanda negatif dengan nilai signifikansi yaitu 0,055 . Maka dapat disimpulkan bahwa tidak adanya pengaruh signifikan terhadap pengungkapan pihak berelasi dengan adanya komisaris independen.

Nilai koefisien regresi dari kepemilikan institusional (KI) yaitu 0,054 serta bertanda negatif dengan nilai signifikansi sebesar 0,035, maka kepemilikan institusional berpengaruh negatif signifikan atas pengungkapan transaksi pihak berelasi. Koefisien regresi dari kepemilikan manajerial (KM) yaitu sebesar 0,028 dan bertanda negatif dengan nilai signifikansi 0,000 maka dapat disimpulkan bahwa kepemilikan manajerial berpengaruh negatif signifikan terhadap pengungkapan transaksi pihak berelasi. Nilai koefisien dari discretionary accruals (DA), yaitu sebesar 0,012 dan memiliki tanda positif serta nilai signifikansi
0,635 sehingga ditarik kesimpulan yaitu manajemen laba yang diukur dengan menggunakan discretionary accruals hasilnya tidak berpengaruh signifikan atas pengungkapan transaksi pihak berelasi. Nilai koefisien dari variabel kontrol yaitu ukuran perusahaan sebesar 0,004 dan bertanda negatif dengan nilai signifikansi 0,796 . Oleh sebab itu, dapat disimpulkan bahwa ukuran perusahaan sebagai variabel kontrol tidak berpengaruh signifikan atas pengungkapan transaksi pihak berelasi.

\section{Pengaruh Komite Audit Terhadap Pengungkapan Transaksi Pihak Berelasi}

Hasil dari penelitian ini menunjukkan bahwa kehadiran komite audit dalam perusahaan tidak berpengaruh atas kepatuhan entitas dalam mengungkapkan informasi transaksi pihak berelasi. Apabila pihak komite audit tidak mempunyai keilmuan memadai pada bidang akuntansi maka tugas dan tanggungjawab komite audit tidak akan terlaksana dengan baik. Sekitar 22\% perusahaan yang dijadikan sampel dalam penelitian ini mempunyai ketua dan/atau anggota komite audit yang berlatarbelakang pendidikan bukan dari akuntansi.

Hal ini mengindikasikan bahwa masih terdapat komite audit tidak secara efektif 
dapat mengawasi kinerja pihak manajemen sehingga dampaknya terhadap luas pengungkapan atas informasi laporan keuangan yang juga tidak akan akan efektif. Para anggota komite audit dituntut untuk mempunyai kapabillitas, keahlian dan pengetahuan dalam bidang audit dan juga pemahaman atas proses bisnis perusahaan sehingga mampu bekerja secara profesional (Effendi, 2016). Hal ini selaras dengan penelitian Alvionita dan Taqwa (2014) serta Kharis dan Suhardjanto (2012) yang mengunkapkan bahwa komite audit dalam perusahaan tidak berpengaruh terhadap kepatuhan pengungkapan wajib.

\section{Pengaruh Komisaris Independen Terhadap Pengungkapan Transaksi Pihak Berelasi}

Hasil dari penelitian ini menunjukkan proporsi komisaris independen tidak memiliki pengaruh atas pengungkapan transaksi pihak berelasi. Tugas dari kehadiran komisaris independen dalam perusahaan pada umumnya adakah memastikan prinsip serta praktik dari tata kelola perusahaan yang baik diterapkan dengan baik. Kedudukan dari pihak komisaris independen dalam perusahaan pada umumnya sama dengan kedudukan dari anggota dewan komisaris lainnya yaitu sebagai pihak yang melakukan pengawasan (Effendi, 2016). Hal ini membuktikan bahwa keberadaan dari pihak komisaris independen hanya sebagai pihak yang melakukan pengawasan saja, tetapi tidak memiliki otoritas dalam melakukan pengambilan keputusan operasional perusahaan.

Sejalan dengan penelitian yang Izzaty dan Kurniawan (2018) serta Gunawan dan Hendrawati (2016) yang menjelaskan jika proporsi komisaris independen bukan penentu tingginya pengungkapan wajib dalam laporan keuangan yang dikeluarkan oleh perusahaan.

\section{Pengaruh Kepemilikan Institusional Terhadap Pengungkapan Transaksi Pihak Berelasi}

Kepemillikan saham oleh pihak institusi pada dasarnya akan menguasai saham secara mayoritas karena sumber daya yang dimiliki oleh institusi lebih banyak apabila dipadankan dengan sumber daya yang berasal dari pemegang saham yang lain. Hasil dari penelitian ini menunjukkan bahwa kepemilikan institusional berpengaruh signifikan dan negatif atas pengungkapan transaksi pihak berelasi. Entitas yang struktur kepemilikan institusionalnya cukup besar biasanya lebih berfokus pada analisis rasio keuangan dibandingkan dengan analisis nonkeuangan. Sari dan Rani (2015) mengungkapkan bahwa pemilik saham institusional akan fokus pada return atas investasinya sehingga entitas akan terpacu melakukan efisiensi atas biaya-biaya yang akan dikeluarkan. Hal ini menjadi dasar bahwa besar ataupun kecilnya persentase kepemilikan saham oleh institusi tidak dapat menajadi jaminan aka luasnya pengungkapan transaksi pihak berelasi.

Perusahaan dengan persentase kepemilikan institusional yang tinggi beranggapan bahwa tidak perlu melakukan pengungkapan informasi yang lebih luas sebab investor institusional lebih berfokus pada analisis rasio keuangan didandingkan memperhatikan aspek pengungkapan laporan keuangan sehingga kepemilikan institusional berpengaruh negatif atas pengungkapan informasi laporan keuangan. Hal ini selaras dengan penelitian Sari dan Rani (2015) dan penelitian Anissa dan Machdar (2019) yang mengungkapkan bahwa kepemilikan institusional berpengaruh negatif atas pengungkapan tanggung jawab sosial perusahaan.

\section{Pengaruh Kepemilikan Manajerial Terhadap} Pengungkapan Transaksi Pihak Berelasi 
Jessyka Tridewi Purba: Determinasi Pengungkapan Transaksi ...

Kepemilikan saham oleh pihak manajemen akan mempengaruhi keputusan dan kebijakan yang akan diambil. Ketika manajer berperan sebagai agen dan prinsipal, maka akan ada dorongan yang kuat untuk melakukan peningkatan nilai perusahaan dan kesejahteraan para pemegang saham perusahaan. Hasil penelitian ini memperlihatkan bahwa kepemilikan manajerial berpengaruh signifikan negatif atas pengungkapan transaksi pihak berelasi. Jika perusahaan yang memiliki kepemilikan manajerial tinggi namun nilai pengungkapan laporan keuangannya rendah, hal tersebut menunjukkan bahwa manajer tidak mampu menyeimbangkan kepentingannya sebagai agen sekaligus prinsipal.

Permanasari (2012) mengemukaan bahwa pada perusahaan keluarga dengan manajemen perusahaan adalah pemilik saham perusahaan, akan memiliki tingkat pengungkapan informasi yang lebih rendah. Manajemen yang juga sebagai pemilik perusahaan tidak membutuhkan informasi tambahan karena manajemen sebagai pemilik akan jauh lebih mudah dalam mengakses infromasi sehingga biaya agen akan menjadi lebih rendah pula. Sehingga kepemilikan saham oleh manajemen akan berpengaruh negatif terhadap pengungkapan laporan keuangan.

Hasil ini sejalan dengan penelitian Permanasari (2012) yang menyatakan bahwa struktur berpengaruh negatif terhadap pengungkapan. Serta penilitan yang dilakukan Purbopangestu dan Subowo (2014) yang menyatakan bahwa kepemilikan manajerial berpengaruh negatif terhadap pengungkapan corporate social responsibility.

\section{Pengaruh Manajemen Laba Terhadap Pengungkapan Transaksi Pihak Berelasi}

Hasil penelitian ini memperlihatkan bahwa manajemen laba tidak memiliki pengaruh terhadap pengungkapan transaksi pihak berelasi. Peraturan mengenai pengungkapan transaksi pihak berlasi yang termasuk dalam pengungkapan wajib yang harus dilakukan oleh perusahaan karena terikat oleh PSAK yang mengatur yaitu PSAK No. 7 mengharuskan perusahaan untuk melakukan pengungkapan pihak-pihak berelasi. Meskipun entitas melakukan manajemen laba baik dengan cara menaikkan laba, menurunkan laba ataupun melakukan perataan laba maka perusahaan tersebut wajib untuk mematuhi peraturan yang berlaku, yaitu melakukan pengungkapan atas transaksi pihak berelasi tanpa ada pengecualian.

Pengungkapan transaksi pihak berelasi ini berlaku untuk seluruh perusahaan tanpa memandang apakah perusahaan memiliki laba yang besar ataupun laba yang kecil. Hal ini sesuai dengan penelitian Fitri (2012) yang menerangkan bahwa perusahaan terindikasi praktik manajemen laba tidak akan mempengaruhi perusahaan dalam melakukan pengungkapan laporan keuangan perusahaan.

\section{PENUTUP}

Hasil penelitian ini menunjukkan bahwa komite audit, komisaris independen, kepemilikan institusional, kepemilikan manajerial, manajemen laba yang dikendalikan oleh ukuran perusahaan hanya dapat mempengaruhi pengungkapan transaksi pihak berelasi sebesar 13\%, sedangkan selebihnya yaitu sebesar $87 \%$ dipengaruhi oleh variabel-variabel lainnya selain variabel yang ada pada penelitian ini. Secara parsial, kepemilikan institusional dan kepemilikan manajerial berpengaruh signifikan terhadap pengungkapan transaksi pihak berelasi. Akan tetapi komite audit, komisaris independen dan manajemen laba tidak berpengaruh terhadap pengungkapan transaksi pihak berelasi.

Berlandaskan kesimpulan tersebut, maka terdapat beberapa implikasi dari hasil penelitian. Perusahaan dapat lebih memperhatikan dan melakukan pengawasan dalam memberikan informasi mengenai 
transaksi pihak berelasi kepada pemakai laporan keuangan. Perusahaan masih cenderung untuk memberi perhatian mengenai informasi keuangan seperti analisis rasio keuangan dibandingkan informasi non-keuangan seperti pengungkapan transaksi pihak terkait. Sebaiknya perusahaan memberi perhatian lebih atas informasi non-keuangan yang berguna untuk para pengguna laporan keuangan.

\section{REFERENSI}

Akmyga, S. F., dan Mita, A. F. (2015). Pengaruh Struktur Corporate Governance Dan Kualitas Audit Terhadap Luas Pengungkapan Kompensasi Manajemen Kunci Di Laporan Keuangan. Jurnal Akuntansi Dan Keuangan Indonesia, 11(1), 19-36.

Alvionita, I., dan Taqwa, S. (2014). Pengaruh Struktur Kepemilikan dan Mekanisme Corporate Governance Terhadap Tingkat Kepatuhan Mandatory Disclosure. Simposium Nasional Akuntansi 17, (2002), 1-23.

Anissa, C. D., dan Machdar, N. M. (2019). Pengaruh Kepemilikan Institusional, Kepemilikan Manajerial dan Profitabilitas terhadap Pengungkapan Tanggung Jawab Sosial Perusahaan. Jurnal Bisnis Dan Komunikasi, 6(1), 918.

Devi, Ida. (2014). Pengaruh Ukuran Perusahaan, Likuiditas, Leverage Dan Status Perusahaan Pada Kelengkapan Pengungkapan Laporan Keuangan. EJurnal Akuntansi, 8(3), 474-492.

Effendi, M. A. (2016). The power of Good Corporate Governance. (D. A. Halim, Ed.) (Edisi 2). Jakarta: Salemba Empat.

Ermaya, H. N. L., dan Astuti, M. (2017). Jurnal mebis. Asimetri Informasi Dan Manajemen Laba Dengan Mekanisme Corporate Governance Sebagai Pemoderasi, 2433(2), 13-23.
Fitri, Y. (2012). Pengaruh Manajemen Laba , Likuiditas Dan Profitabilitas Terhadap Tingkat Keuangan Tahunan. FE UNP Padang, 1-16.

Ghozali, H. I. (2018). Aplikasi Analisis Multivariate Dengan Program IBM SPSS 25. Semarang: Universitas Diponegoro.

Gunawan, B., dan Hendrawati, E. R. (2016). Peran Struktur Corporate Governance Dalam Tingkat Kepatuhan Pengungkapan Wajib Periode Setelah Konvergensi IFRS (Studi pada Perusahaan Manufaktur yang Terdaftar di Bursa Efek Indonesia). Berkala Akuntansi Dan Keuangan Indonesia, 1(1), 71-83.

Hamdani. (2016). Good Corporate Governance. Jakarta: Mitra Wacana Media.

Harijanto, V. N. A. (2019). Pengungkapan Transaksi Berelasi Berdasarkan PSAK No. 7 Tentang Pengungkapan Pihak-Pihak Berelasi. Jurnal Nominal, Barometer Riset Akuntansi Dan Manajemen, VIII(7), 59-70.

Ikatan Akuntan Indonesia. Pernyataan Standar Akuntansi Keuangan (PSAK) No. 7 Tahun 2018.

Izzaty, K. N., dan Kurniawan, P. C. (2018). Pengaruh Kinerja Keuangan, Struktur Kepemilikan Dan Corporate Governance Terhadap Tingkat Kepatuhan Pengungkapan, 8, 215-228.

Keputusan Ketua Bapepam dan LK Nomor:KEP-412/BL/2009. Transaksi Afiliasi dan Benturan Kepentingan Transaksi Tertentu.

Kharis, A., dan Suhardjanto, D. (2012). Corporate Governance Dan Ketaatan Pengungkapan Wajib Pada Badan Usaha Milik Negara. Jurnal Keuangan Dan Perbankan, 16(1), 37-44.

Lobu, G. J., dan Zhou, J. (2001). Disclosure Quality and Earnings Management. Social Science Research Network Electronic Paper Collection, 1-20. 
Permanasari, M. (2012). Pengaruh Karakteristik Perusahaan dan Mekanisme Corporate Governance Terhadap Pengungkapan Informasi. Jurnal Bisnis Dan Akuntansi, 14(3), 193212.

Pratista, A. R. H. (2019). Pengaruh Corporate Governance Pada Kepatuhan Pengungkapan Transaksi Berelasi Berdasarkan Pernyataan Standar Akuntansi Keuangan (PSAK) NO. 7 Tahun 2015. Jurnal Nominal, Baromeer Riset Akuntansi Dan Manajemen, VIII(7), 1930.

Prior, D., Surroca, J., dan Tribó, J. A. (2008). Are socially responsible managers really ethical? Exploring the relationship between earnings management and corporate social responsibility. Corporate Governance: An International Review, 16(3), 160-177.

Purbopangestu, H. W., dan Subowo. (2014). Pengaruh Good Corporate Governance Terhadap Nilai Perusahaan Dengan Corporate Social Responsibility Sebagai Variabel Intervening. Accounting Analysis Journal, 3(3), 321-333.

Sari, W. N., dan Rani, P. (2015). Pengaruh Kepemilikan Institusional, Kepemilikan Manajerial, ROA dan Ukuran Perusahaan Terhadap CSR Pada Perusahaan Manufaktur yang Terdaftar di BEl Periode 2011-2013. Jurnal Akuntansi Dan Keuangan, 4(1), 1-20.

Sulistyanto, H. S. (2008). Manajemen Laba; Teori dan Model Empiris. Jakarta: Grasindo. 